\title{
Online Learning and Platforms Favored in Physical Education Class during COVID-19 Era: Exploring Student' Perceptions
}

\author{
Hasanuddin Jumareng ${ }^{1, *}$, Edi Setiawan², Ihsan Abdul Patah'², Mela Aryani ${ }^{2}$, Asmuddin ${ }^{1}$, \\ Ruslan Abdul Gani ${ }^{3}$

\begin{abstract}
${ }^{1}$ Department of Physical Education Health and Recreation, Universitas Halu Oleo, Kendari 93231, Indonesia ${ }^{2}$ Department of Physical Education Health and Recreation, Universitas Suryakancana, Cianjur, Jawa Barat 43216, Indonesia ${ }^{3}$ Department of Physical Education Health and Recreation, Universitas Singaperbangsa Karawang, Jawa Barat 41360, Indonesia
\end{abstract}

Received November 15, 2020; Revised January 4, 2021; Accepted January 20, 2021

\section{Cite This Paper in the following Citation Styles}

(a): [1] Hasanuddin Jumareng, Edi Setiawan, Ihsan Abdul Patah, Mela Aryani, Asmuddin, Ruslan Abdul Gani , "Online Learning and Platforms Favored in Physical Education Class during COVID-19 Era: Exploring Student' Perceptions," International Journal of Human Movement and Sports Sciences, Vol. 9, No. 1, pp. 11 - 18, 2021. DOI: 10.13189/saj.2021.090102.

(b): Hasanuddin Jumareng, Edi Setiawan, Ihsan Abdul Patah, Mela Aryani, Asmuddin, Ruslan Abdul Gani (2021). Online Learning and Platforms Favored in Physical Education Class during COVID-19 Era: Exploring Student' Perceptions. International Journal of Human Movement and Sports Sciences, 9(1), 11 - 18. DOI: 10.13189/saj.2021.090102.

Copyright $\subseteq 2021$ by authors, all rights reserved. Authors agree that this article remains permanently open access under the terms of the Creative Commons Attribution License 4.0 International License

\begin{abstract}
The current COVID-19 pandemic becomes a problem for education, especially in the physical education learning process at the university level. The aim of this study is explore students' perceptions of online learning and preferred platforms in physical education classes during the COVID-19 pandemic. The method in this research was a qualitative exploratory study by interview. There were as many as 60 students became the sample from Suryakancana and Halu Oleo University. Data collection is done by interviews to find out student perceptions about the online learning and preferred platforms in physical education classes. The results of this study showed the different perceptions of students regarding online learning and platform favored in the midst of the COVID-19 pandemic, from those who consider online learning to be very helpful and some are highlighting the obstacles faced when implementing online learning. Overall, students' perceptions consider online learning very important in the current era of COVID-19, and the majority of the platforms that students like the most are Zoom Meetings. The contribution of this research can provide information to teachers and lecturers about online learning and platforms that can be used in physical education classes, so that later learning outcomes from
\end{abstract}

students can be achieved more optimally.

Keywords Students' Perceptions, Online Learning, Platforms, Physical Education, COVID-19

\section{Introduction}

In the current era of COVID-19 the use of online-based learning is increasing rapidly in the world [1], including Indonesia and become one of the important lessons [2], for lecturers to carry out education at the university level. Currently research on online-based learning is becoming a trend among researchers, for example previous studies tried to analyze the factors that support or fail in online learning [3], [4], [5]. Another study tried to analyze the factors that influence student satisfaction in implementing online-based learning [6], [7]. Then a study conducted by Chuan Wei and Chou [2] tried to explore students' perceptions of online learning performance and satisfaction. The majority of previous studies on student perceptions of online learning only focused on general education [8], and partly scrutinizing difficulties or 
planning an efficient operation middle and high school online physical education classes, no studies have investigated student perceptions of online learning and preferred platforms in PE classes during the COVID-19 pandemic. In addition, there are still problems regarding online learning, as reported by Brom et al [9] that online-based distance education is burdensome for families, schools and students at all levels. With the gap of online learning in general education classes, this is the reason why online learning must be continuously analyzed and evaluated, especially in PE classes. According to Jeong and So [10] that online PE classes require special preparation to communicate and practice the values of physical education well, so that there is a need to analyze students' perceptions of online education in PE to ensure that online learning can be used to transfer theoretical and practical knowledge which is usually done directly to face. The urgency of this research problem is the importance of facts about the online learning process in PE classes, so that the findings from this research analysis can provide information for lecturers, teachers and practitioners as consideration or evaluation to carry out better online learning in the future and allow institutions to improve their services both in terms of quantity and quality. This study aims to determine students' perceptions of online learning and preferred platforms in PE class during the COVID-19 era

\section{Literature Review}

\subsection{Students' Perceptions On Online Learning}

Online learning uses the internet network, so that lecturers and students can interact in cyberspace [11]. Online is learning that uses internet networks with accessibility, connectivity, flexibility, and the ability to generate various types of interactions in learning [12]. Online learning can create active, innovative, and efficient learning because it can be accessed anywhere and anytime [13]. Students' perceptions about online learning show positive results and they consider that the use of technology in learning is very important to support optimal learning outcomes [14], [15]. Teachers, lecturers, experts or researchers from various disciplines, including $\mathrm{PE}$, are interested in discussing the perceptions of student learning experiences about online learning at the university level. For example Kuo et al [16] reported that online learning is more student-centered which causes them to be able to bring up responsibility and autonomy in learning (learning autonomy). Learning online requires students to prepare all their learning tools, evaluate, organize and simultaneously maintain motivation in independent learning [17]. Similarly, the results of the research by Cho and Shen [18] reported that online learning has the benefit of being able to foster self-regulated learning, however there must still be strict supervision by the lecturer so that students can learn the lesson optimally. Based on this fact, a question arises whether students' perceptions of online learning will be related to better learning outcomes. For example research Wei and Chou [2] finding the first week of online courses can help students perceive online learning more positively, for example, students can decide the best time and location to study, and online learning can facilitate students to study independently, getting more learning resources to solve problems when studying. However, different results are reported by Bali and Lie [19] that students' perceptions of online learning are a lack of interactivity, a low amount of social attendance and a lack of satisfaction among students, so it can be interpreted that online learning is less effective than face-to-face learning. With the contradictory results regarding perceptions of online learning in previous studies, attention is needed and further exploration about online learning, especially in PE class during the COVID-19 pandemic.

Based on the above literature, several factors can be viewed as a consideration for students' perceptions of online learning. For example, online learning provides students with a learning environment that is more flexible, easy and more comfortable to do than face-to-face learning. Then even though online learning can be accessed anywhere and anytime, students must consider a comfortable place and condition and have adequate internet access and learning resources or media available for them to do learning. In addition, the advantages and disadvantages are felt when implementing online learning. Therefore, the concept of student perceptions in this study refers to online learning in PE class against the things described above. It is proposed that the perception of online learning can provide broad benefits in the field of PE.

\subsection{Online Learning Model}

To carry out online learning there are several models that can be implemented in order to create effective online learning. Models that can be used include:

\subsubsection{TPACK Model}

Technology, Pedagogy and Content Knowledge (TPACK) is a model that offers online learning that is different, because it combines several dimensions. This model offers seven dimensions: CK (Content Knowledge), PK (Pedagogical Knowledge), TK (Technological Knowledge), CPK (Pedagogical Knowledge) Content Knowledge), TCK (Technological Content Knowledge), TPK (Technological Pedagogical Knowledge), and TPCK (Technological Pedagogical Content Knowledge) [20]. This model has been claimed by some researchers as a model and tool that greatly contributes to determining success in implementing online learning. 


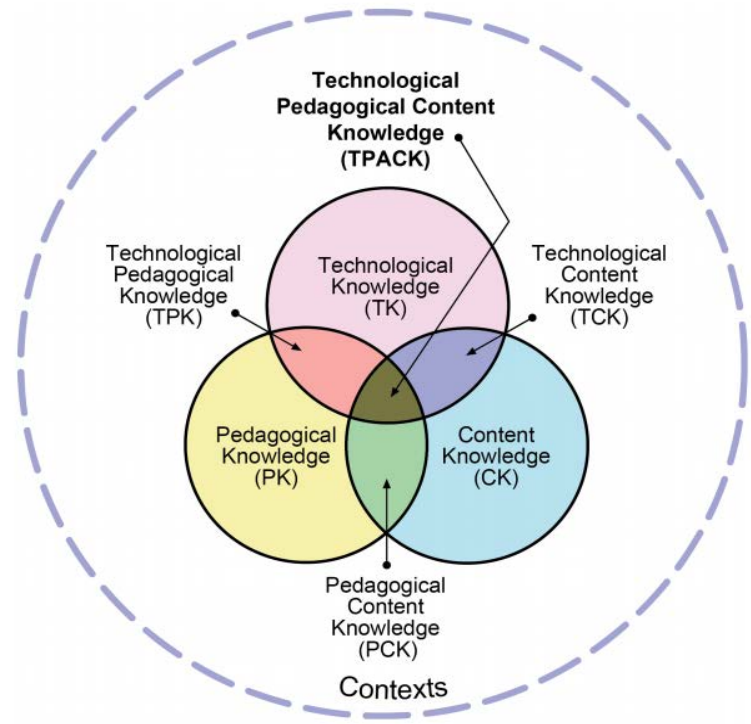

Figure 1. TPACK Framework

\subsubsection{SAMR Model}

Substitution, Augmentation, Modification and Redefinition (SAMR) A model that has the concept of learning phases from substitution (initial contact with technology) to redefinition (mastery of education) technology).The first two phases correspond to the process of improvement in the way of integrating ICT, and the next two phases are in the process of transformation. Each phase can be characterized by the role of technology in the teaching practice. Substitution, technology acts as a direct tool substitute, without any functional change. Augmentation, technology acts as a direct substitute tool, with functional improvement. Modification, the technology allows redesigning important task. Redefinition, technology allows the creation of new tasks, previously inconceivable [20].

\subsection{Students' Perceptions on Platforms Favored}

To carry out online learning effectively and efficiently, lecturers and students really need mobile devices such as smartphones [21], tablets [22] that are connected to the use of a platform [23], such as Zoom Meeting, Webex, Google Meet, Google Classroom, Edmodo [24], Schoology, or WhatsApp [25]. The platform is a tool or vehicle on the internet and has a function to facilitate distance learning between lecturers and students. Students' perceptions about the platform are very important and must be disclosed of their effectiveness, because the use of the platform will determine success in implementing online learning in the future. For example, Benta, Bologa and Dzitac [26] reported the results of their research that the Moodle platform was proven to be useful to assist and strengthen students in submitting homework to lecturers and lecturers could check student assignments anytime and anywhere. The platform is claimed to be one of the key success factors when implementing online learning, because the platform can facilitate interaction between students and lecturers [27]. In addition, the platform can share all kinds of information, such as text, images, video or sound, so that lecturers can distribute study assignments, arrange delivery, can provide assessments of student learning assignments and can monitor the implementation of learning carried out by students [28]. However, the problem is that if the lecturer is not literate in operating the platform it will hinder the learning process, even the learning outcomes will not be maximally achieved [29].

Based on the above literature, several factors can be viewed as a consideration of students' perceptions of preferred platforms. For example the preferred platform and easy to use during PE. Then does the use of platforms have an impact on learning outcomes in PE classrooms during COVID-19.

\section{Materials and Methods}

\subsection{Methods}

In this study using qualitative methods [30], [11] and quantitative (mixed method), so that the data obtained is verbal and numeric from the participants.

\subsection{Participation}

Participation in this study is $60 \mathrm{PE}$ students drawn from levels 3 and 4 from the Suryakancana $(n=30)$ and Halu Oleo $(n=30)$ University. For more details, the characteristics of the subject can be seen in Table 1 .

Table 1. The Characteristics of Participation

\begin{tabular}{ccc}
\hline Age (year) & Height $(\mathrm{cm})$ & Weight $(\mathrm{kg})$ \\
\hline $19.7 \pm 1.01$ & $1.68 \pm 1.73$ & $59.97 \pm 4.20$ \\
\hline
\end{tabular}

The value can be presented as mean \pm deviation standard

The sampling technique used purposive sampling, therefore we choosing students from level 3 and 4 to participate in this research is because they have been doing online learning for 2 semesters, so they know more about online learning in the era of COVID-19.

\subsection{Research Procedure}

This research has received permission from the Suryakancana and Halu Oleo University committee with number E 19/11/2020 and obtain approval from the parents of students. In addition, this study has followed the Ethics guidelines from the World Medical Association (Helsinki Declaration). Before the research is carried out, the subject is asked to make a written statement regarding 
the willingness to participate in all activities in this study.

\subsection{Data Collection Technique}

Data collection and analysis procedures should be clearly explained with a reference to the role and competency of the researcher(s). Five questions have been validated by 3 experts who have expertise related to online learning. Interviews with respondents were conducted for two days with a duration of 5 hours. On the first day conducting interviews with 30 respondents and on the second day conducting interviews with 30 respondents. The data technique in this study was in-depth interviews via WhatsApp. The aspects that were asked in the interview were:

1. Do PE students have the facilities and infrastructure to carry out online learning?

2. What makes online learning successful compared to traditional learning?

3. What platforms are often used by lecturers in online learning?

4. What is the most preferred platform for PE students?

5. How do PE students perceive the advantages and disadvantages of online learning?

The five questions in this study were adapted from Kim [31], but the modification researcher became five questions. In addition, this instrument has been tested beforehand and has validity (0.88) and reliability (0.78), so this instrument is valid for scientific research.

\subsection{Data Analysis Technique}

After conducting observations and interviews with 60 students, documentation data was collected, using analytical data collection techniques and data collection, using three stages, namely (a) data reduction, (b) data display, and (c) drawing conclusions from data analysis, namely the process of analyzing data collection, in accordance with the formulation of the problem, then also proven by the results of data processing in narrative form. Comments from informants (data display in the process of becoming narrative comments).

\section{Result}

Question 1: What is the Media needed to carry out online learning?

Respondents answered:

"Media equipment is a very important factor and it is needed to support the implementation of online learning effectively during PE lectures. Smartphones, laptops and the internet are tools that will facilitate and assist students in obtaining all material presented by lecturers. However, if students do not have smartphones and laptops, it will obstruct the learning process and they have to buy these tools with a lot of money and of course it takes a relatively long time to buy the tools. So in my opinion that smartphones and laptops are the main tools students need to achieve optimal online learning in the COVID-19 era."

Other respondents added regarding the first question:

"There are several media equipment that must be prepared by students, one of which is a laptop and internet access when doing online learning at home. Laptops are used to be able to access the zoom site, so that we can interact via cyberspace with other friends and lecturers. Without a laptop and internet network, it is certain that online learning cannot be implemented and we will not get knowledge from lecturers."

The responses from other respondents stated:

"Media tools needed to carry out online learning are laptops, smartphones and adequate internet access. With all these tools, we can easily access the zoom site, Google Meet, Google Classroom that is commonly used by lecturers in conducting online learning. Thus, to achieve optimal learning outcomes, all media equipment must be prepared before participating the online learning."

Question 2: What makes online learning successful compared to face-to-face (offline) learning?

The respondent' answered:

"The spread of COVID-19 in Indonesia, especially in the Cianjur region, is very rapid and massive. The first way to avoid COVID-19 is to maintain social distancing (for example 2 meters) with people who is positive for this virus. To prevent the widespread of COVID-19 among PE students, online learning is the best way for now. In addition, online learning can increase our learning motivation to be better than face-to-face learning."

Other respondents stated that:

"Online learning is less successful than face-to-face learning, because PE learning is synonymous with motion. If motion learning is carried out online, it will be difficult for students to understand, especially the movements exemplified by the lecturers are relatively difficult. Like the movement of pencak silat, other than that lectures that require equipment will be difficult to do online such as physical test and measurement courses, badminton, volleyball, handball, because all the equipment used is only available on campus."

There were also respondents who answered:

"Various efforts to suppress the chain of COVID-19 spread in the campus environment, one of which is 
by implementing online learning. Online learning is an effective strategy to use today, because with online learning students and lecturers do not need to do PE learning directly (face to face), so that in this way it can minimize the occurrence of COVID-19 transmission. In addition, online learning has advantages compared to face-to-face learning, learning can be accessed anywhere. such as on the home page, home page or in the room. By implementing online learning, we make it easier for us to learn PE subject matter given by the lecturer."

Question 3: What platforms are often used by lecturers in online learning?

The respondent' answered:

"Each platform has advantages and disadvantages, but most PE lecturers often use the Zoom Meeting platform to carry out online learning in PE classes. In one semester lectures, both theoretical and practical, the lecturers always instruct us to do learning via Zoom Meetings, because this platform really makes easy for students, for example the Zoom Meeting platform is easy to access and can save files easily."

Another respondent added an answer:

"At the beginning of the online lecture, the lecturers introduced and instructed students to use the Zoom Meeting platform. The Zoom Meeting platform has its own advantages, it displays someone who is talking, then it can give messages to all participants in the Zoom Room and can send messages privately to the target person."

There were also respondents who answered:

"At the beginning of the semester the lecturers introduced the Zoom Meeting platform and Schoology to us, as a medium to support online learning. At the beginning of our meeting it was difficult to operate the platform, because it uses English, but as the lecture progressed we began to understand and understand how to run all the features on the platform. Thus the platform most often used by PE lecturers is the Zoom Meeting."
Question 4: Which platform do students like the most?

Several respondents answered:

"The Zoom Meeting and Google Classroom platform are my favorite learning media, because these platforms are very easy to access. Apart from that it's easy to send video files and save other files. However, the lack of the Google Classroom platform is that it cannot make video calls with friends or lecturers. Meanwhile, Zoom Meetings are better, because apart from being able to store files easily, this platform can also make video calls or meet face to face with lecturers in cyberspace. However, there are still some shortcomings in this Zoom Meeting platform, namely there is a minimum time limit for use of 45 minutes, when that time is up, the user will automatically exit the Zoom Meeting platform and when they want to re-enter they must use a different id and password."

And others claim that:

"There are many media or platforms that exist today, but to be able to access all of these learning media requires a lot of internet quota, I tend to prefer to use the WhatsApp media. If you look at the impact of COVID-19, where many parents of students have difficulty finding money and many have terminated their employment contracts, the WhatsApp platform will be much more useful than other learning media. Many lecturers instruct me to use the Zoom Meeting and Schoology platform at the beginning of online lectures, but I prefer to use Google Classroom, because the platform has advantages: (1) Easy to access, (2) Do not require a large internet quota, (3) It has the feature that is easy to understand, (4) Can save large files, (5) Can see assignments given by lecturers easily, but this platform also has shortcomings, (6) Cannot make video calls with friends or lecturers." The majority of respondents chose Zoom Meeting with a percentage of $30.00 \%$ as the most preferred platform and often used in the PE learning process in theory and practice. Meanwhile, the platform that the respondents did not like was Schoology with a percentage of $3.33 \%$ (see fig. 2). 


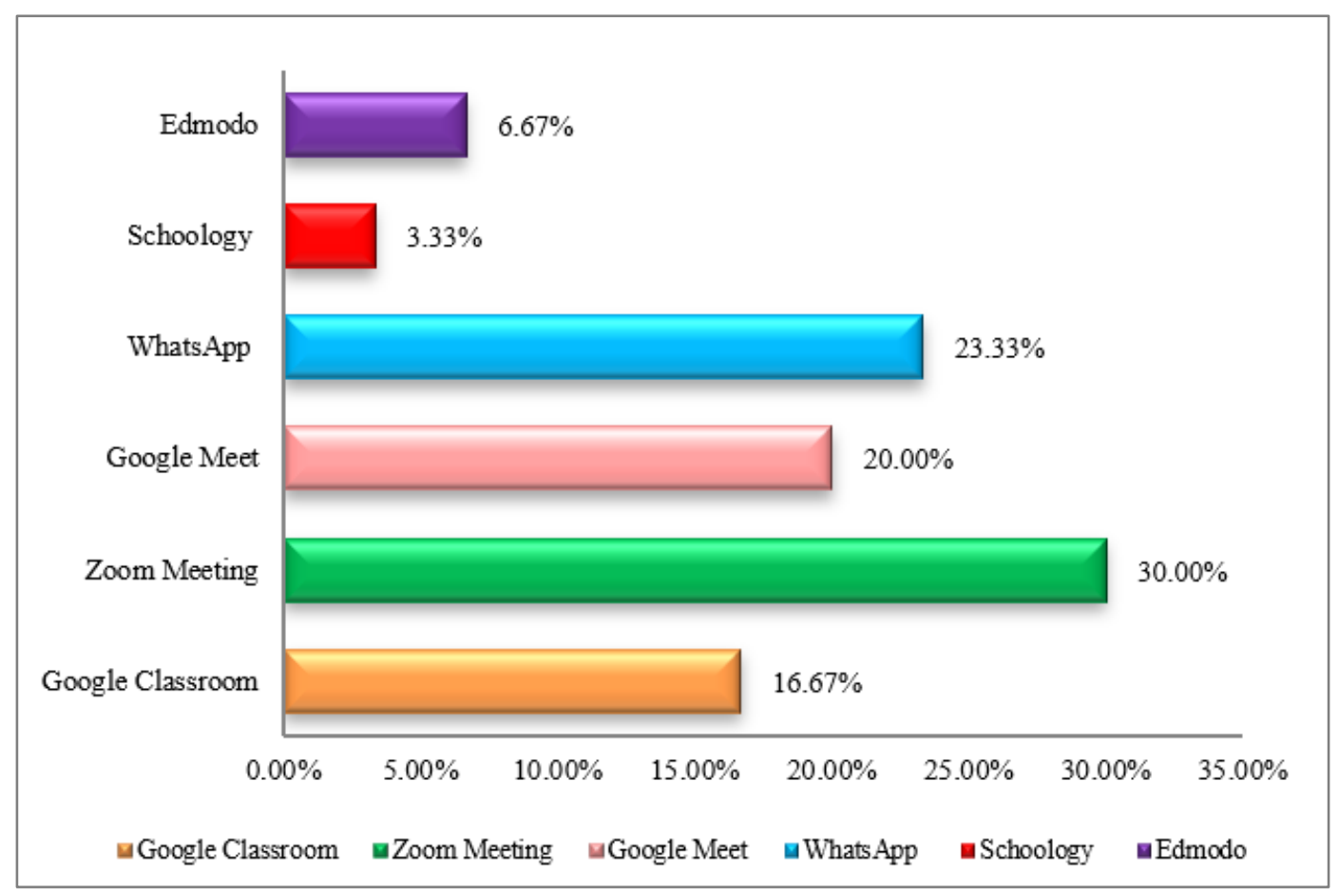

Figure 2. Percentage of platforms students liked

Question 5: How do students perceive the advantages and disadvantages of online learning?

Respondent said:

"Every learning design or pattern that is applied has its advantages and disadvantages, in this case is the online learning. On the other hand, online learning can protect students and lecturers from spreading the COVID-19 epidemic, but online learning can be burdensome the students and their parents, because they have to prepare smartphones, laptops and internet quotas with relatively expensive prices."

Most of respondents said:

"By using smartphones or other technological devices, such as laptops connected to the internet, we can already access the material we want to study. By implementing online learning we can do learning anywhere and anytime. Especially with the current conditions with no crowds or large gatherings are allowed, online learning is the most effective strategy to use in obtaining information. However, there are limitations, namely internet access in remote areas that is not always stable, so that it is the main obstacle for us to participate in the online learning process. Thus, online learning is good to use amid the current COVID-19, but the availability of internet access is a major problem for us. Because not all students have adequate finance. I hope the university can solve this problem by giving students free internet quota in one semester to carry out online learning."
In addition to the data presented in the verbal form of the participants, this study is also presented in the form of mean, standard deviation and percentage (see Table 2).

Table 2. Results of student perception assessment

\begin{tabular}{ccccc}
\hline N0. & Question & Mean & $\begin{array}{c}\text { Standard } \\
\text { deviation }\end{array}$ & Percentage \\
\hline 1. & Q1 & 2.53 & 0.85 & 63.33 \\
2. & Q2 & 2.77 & 0.81 & 69.17 \\
3. & Q3 & 2.60 & 0.81 & 65.01 \\
4. & Q4 & 2.73 & 0.84 & 68.33 \\
5 & Q5 & 2.63 & 0.86 & 65.83 \\
\hline
\end{tabular}

\section{Discussions}

The purpose of this study was to explore students' perceptions of online learning and the platforms they preferred during the COVID-19 pandemic. The results of this study indicate that the majority of respondents' perceptions admit that online learning is better and effective used for now than face-to-face learning. In addition, they feel online learning more interesting and easy to access at any time. Similar with previous research show online learning has been proven effective in improving student learning achievement and is claimed to be a learning solution in the era of COVID-19 [32], [33]. However, this study found there are many shortcomings and problems related to online-based learning that implicate lecturers and students, for example students do not focus on subject matter or difficult learning tasks, so 
they cannot learn them optimally, bad internet network and not all students have internet quota. The same problem was found in previous studies which reported that online-based learning caused several problems to students, such as a bad internet network, and many students do not have internet connectivity at home [34]. Another finding reports that if lecturers and students are less skilled in operating online learning media, learning outcomes will not be achieved [35]. In line with the results of this study, many respondents reported having difficulty operating the Schoology or Zoom Meeting platform at the beginning of lectures. Then in this study found that the majority of respondents chose the Zoom Meeting platform (30.00\%) as the most preferred and commonly used platform in the PE online learning process. However, it is different from the results of previous studies which show that the majority of respondents choose DingTalk (56.65\%) and WeChat (52.75\%) which are often used in the online learning process [36].

Some suggestions that can be applied to overcome distance learning problems for motor skills in learning kinetic sports activities such as swimming or other activities such as gymnastics, basketball, include: (1) demonstration the movements that students will learn through the zoom meeting platform, (2) provide videos or digital textbooks about the subject matter to students, (3) instruct students to do exercises independently at home, (4) provide feedback to students whenever they need.

\section{Conclusions}

The majority of students have a good perspective on online learning and they consider that online learning in PE class is very helpful for learning theoretical and practical subject matter in the COVID-19 era, although it is not completely efficient because there are several obstacles faced when learning online. There are several suggestions that are thought to be effective for achieving optimal online learning in PE courses, such as: (1) the University must start paying attention and provide free internet quota to students, (2) lecturers must better understand and provide motivation if there are students who being late in online learning, (3) not giving assignments too often, but increase the discussion with students when carrying out online learning. (4) create innovations in learning, such as implementing a blended learning model [37]. However, this study still has limitations, as follows: The subjects involved in this study were relatively few, namely only two PE university in Indonesia, thus limiting the generalizability of research findings to other universities. Future studies need to involve the perceptions of students from other PE universities in Indonesia and also have to compare the results of other PE universities that organize online learning.

\section{Acknowledgements}

Many thanks to Suryakancana University and also Physical Education students who have been willing to be respondents in this research.

\section{REFERENCES}

[1] H. Cigdem and O. G. Yildirim, "Effects of students' characteristics on online learning readiness: A vocational college example,” Turkish Online J. Distance Educ., vol. 15, no. 3, pp. 80-93, 2014.

[2] H. C. Wei and C. Chou, "Online learning performance and satisfaction: do perceptions and readiness matter?,” Distance Educ., vol. 41, no. 1, pp. 48-69, 2020.

[3] D. U. Bolliger and C. Halupa, "Online student perceptions of engagement, transactional distance, and outcomes," Distance Educ., vol. 39, no. 3, pp. 299-316, 2018.

[4] B. E. Shelton, J. L. Hung, and P. R. Lowenthal, "Predicting student success by modeling student interaction in asynchronous online courses,” Distance Educ., vol. 38, no. 1, pp. 59-69, 2017.

[5] D. Yang, "Instructional strategies and course design for teaching statistics online: perspectives from online students," Int. J. STEM Educ., vol. 4, no. 1, 2017.

[6] S. S. Liaw and H. M. Huang, "Perceived satisfaction, perceived usefulness and interactive learning environments as predictors to self-regulation in e-learning environments," Comput. Educ., vol. 60, no. 1, pp. 14-24, 2013.

[7] J. Weidlich and T. J. Bastiaens, "Technology matters - The impact of transactional distance on satisfaction in online distance learning," Int. Rev. Res. Open Distance Learn., vol. 19, no. 3, pp. 222-242, 2018.

[8] P. Fidalgo, J. Thormann, O. Kulyk, and J. A. Lencastre, "Students' perceptions on distance education: A multinational study," Int. J. Educ. Technol. High. Educ., vol. 17, pp. 1-18, 2020.

[9] C. Brom, J. Lukavský, D. Greger, T. Hannemann, and J. Straková, "Mandatory Home Education During the COVID-19 Lockdown in the Czech Republic: A Rapid Survey of 1st-9th Graders ' Parents,” Br. Res. Rep., vol. 5, no. July, pp. 1-8, 2020.

[10] H. C. Jeong and W. Y. So, "Difficulties of online physical education classes in middle and high school and an efficient operation plan to address them," Int. J. Environ. Res. Public Health, vol. 17, no. 19, pp. 1-13, 2020.

[11] C. Rapanta, L. Botturi, P. Goodyear, L. Guàrdia, and M. Koole, "Online University Teaching During and After the Covid-19 Crisis: Refocusing Teacher Presence and Learning Activity,” Postdigital Sci. Educ., no. July, pp. 1-23, 2020. 
[12] J. L. Moore, C. Dickson-deane, and K. Galyen, "Internet and Higher Education e-Learning, online learning, and distance learning environments : Are they the same?," Internet High. Educ., vol. 14, no. 2, pp. 129-135, 2011.

[13] Z.-Y. Liu, N. Lomovtseva, and E. Korobeynikova, “Online Learning Platforms: Reconstructing Modern Higher Education,” Int. J. Emerg. Technol. Learn., vol. 15, no. 13, pp. 4-21, 2020.

[14] M. G. Alzahrani and J. M. O’Toole, “The Impact of Internet Experience and Attitude on Student Preference for Blended Learning,” J. Curric. Teach., vol. 6, no. 1, p. 65, 2017.

[15] H. Wei, H. Peng, and C. Chou, "Computers \& Education Can more interactivity improve learning achievement in an online course? Effects of college students' perception and actual use of a course-management system on their learning achievement," Comput. Educ., vol. 83, pp. 10-21, 2015.

[16] Y. Kuo, A. E. Walker, K. E. E. Schroder, and B. R. Belland, "Internet and Higher Education Interaction, Internet self-efficacy, and self-regulated learning as predictors of student satisfaction in online education courses," Internet High. Educ., vol. 20, pp. 35-50, 2014.

[17] S. Y. H. Sun, "Learner perspectives on fully online language learning,” Distance Educ., no. April, pp. 1-25, 2015.

[18] M. Cho and D. Shen, "Self-regulation in online learning," Distance Educ., vol. 34, no. 3, pp. 290-301, 2013.

[19] S. Bali and M. C. Liu, "Students’ perceptions toward online learning and face-to-face learning courses,” J. Phys. Conf. Ser., vol. 1108, no. 1, pp. 1-7, 2018.

[20] M. L. Cacheiro-Gonzalez, A. Medina-Rivilla, M. C. Dominguez-Garrido, and M. Medina-Dominguez, "The learning platform in distance higher education: Student's perceptions,” Turkish Online J. Distance Educ., vol. 20, no. 1, pp. 71-95, 2019.

[21] J. Gikas and M. M. Grant, "Internet and Higher Education Mobile computing devices in higher education: Student perspectives on learning with cellphones, smartphones \& social media," Internet High. Educ., vol. 19, pp. 18-26, 2013.

[22] S. Gokçearslan, F. K. Mumcu, T. Haslaman, and Y. D. Cevik, "Modelling smartphone addiction: The role of smartphone usage, self-regulation, general self-efficacy and cyberloafing in university students," Comput. Hum. Behav. J., vol. 63, pp. 639-649, 2016.

[23] V. Singh and A. Thurman, "How Many Ways Can We Define Online Learning? A Systematic Literature Review of Definitions of Online Learning ( 1988-2018 ),” Am. J. Distance Educ., vol. 33, no. 4, pp. 289-306, 2019.

[24] M. A. S. Enriquez, "Students' Perceptions on the Effectiveness of the Use of Edmodo as a Supplementary Tool for Learning," Present. DLSU Res. Congr., pp. 1-6,
2014.

[25] S. So, "Mobile instant messaging support for teaching and learning in higher education,” Internet High. Educ., vol. 31, pp. 32-42, 2016.

[26] D. Benta, G. Bologa, and I. Dzitac, "E-learning Platforms in Higher Education. Case Study E-learning Platforms in Higher Education. Case Study,” Procedia Comput. Sci., vol. 31, no. June, pp. 1170-1176, 2014.

[27] C. H. Huang, S. L. Chin, L. H. Hsin, J. C. Hung, and Y. P. $\mathrm{Yu}$, "A Web-based E-learning Platform for physical education,” J. Networks, vol. 6, no. 5, pp. 721-727, 2011.

[28] T. Goad, B. Towner, E. Jones, and S. Bulger, “Instructional Tools for Online Physical Education: Using Mobile Technologies to Enhance Learning,” J. Phys. Educ. Recreat. Danc., vol. 90, no. 6, pp. 40-47, 2019.

[29] C. J. Leacock and S. J. Warrican, "Helping teachers to respond to COVID-19 in the Eastern Caribbean: issues of readiness, equity and care,” J. Educ. Teach., vol. 00, no. July, pp. 1-10, 2020.

[30] P. Jandric, "Postdigital Research in the Time of Covid-19," Postdigital Sci. Educ., vol. 2, no. March, pp. 1-6, 2020.

[31] J. Kim, "Learning and Teaching Online During Covid-19: Experiences of Student Teachers in an Early Childhood Education Practicum,” Int. J. Early Child., vol. 52, no. 2, pp. 145-158, 2020.

[32] T. Mutton, "Teacher education and Covid-19: responses and opportunities for new pedagogical initiatives," J. Educ. Teach., vol. 00, no. 7, pp. 1-3, 2020.

[33] G. Basilaia and D. Kvavadze, "Transition to Online Education in Schools during a SARS-CoV-2 Coronavirus (COVID-19) Pandemic in Georgia,” Pedagog. Res., vol. 5, no. 4, pp. 1-9, 2020.

[34] P. Ramakrisnan, Y. bt Y. Yahyaa, M. N. H. Hasrol, and A. A. Aziz, "Blended Learning: A Suitable Framework For E-Learning In Higher Education,” Procedia - Soc. Behav. Sci., vol. 67, pp. 513-526, 2012.

[35] W. Zhang, Y. Wang, L. Yang, and C. Wang, "Suspending Classes Without Stopping Learning: China' s Education Emergency Management Policy in the COVID-19 Outbreak," J. Risk Financ. Manag., vol. 13, no. 55, pp. 1-6, 2020.

[36] X. Yang, “Teachers' Perceptions of Large-Scale Online Teaching As an Epidemic Prevention and Control Strategy in China,” ECNU Rev. Educ., no. April, pp. 1-6, 2020.

[37] E. Kastrena, E. Setiawan, and A. Adawiyah, "Moving from Traditional Teaching to Blended Learning in the Teaching and Learning of Sports Test and Measurement Course to Improve Students' Learning Outcomes," 2nd Int. Conf. Innov. Exhib. Glob. Educ., no. September, pp. 146-151, 2020. 